\title{
Effect the Addition of Sweet Whey on the Survival of Lactobacillus Reuteri in the Therapeutic Ice Cream
}

\section{Ali Ameen Yaseen}

Department of Food Science, Collage of Agriculture, Anbar University. Iraq

Correspondence Author: Ali Ameen Yaseen, Department of Food Science, Collage of Agriculture, Anbar University. Iraq.

Received date: 11 April 2018, Accepted date: 15 June 2018, Online, Online date: 25 June 2018

Copyright: (C) 2018 Ali Ameen Yaseen. This is an open-access article distributed under the terms of the Creative Commons Attribution License, which permits unrestricted use, distribution, and reproduction in any medium, provided the original author and source are credited.

\begin{abstract}
The current study indicated to the positive role of sweet whey in increasing the number of Lactobacillus reuteri in the therapeutic ice cream during manufacturing and storage. The study showed a significant increasing $(\mathrm{p}<0.05)$ in the number of living bacteria during manufacturing from $40 \times 106$ c.f.u. /g to $23 \times 108$ c.f.u/g in the normal formulation, while the number of bacteria arrived to $13 \times 109,80 \times 109$ and $19 \times 1011$ c.f.u. /g in the formulations where the whey was replaced instead of water by $20 \%, 40 \%$ and $60 \%$ respectively. The study also showed the protection role of the ingredients of formulation and sweet whey during freezing process, whereas the number of bacteria increased to $140 \times 148 \mathrm{c.f} . \mathrm{u}$. $/ \mathrm{g}$ in the normal product, while the number of bacteria arrived to $25 \times 109,24 \times 1011$ and $30 \times 1012$ c.f.u. /g in products where whey was replaced instead of water o formulation by $20 \%, 40 \%$ and $60 \%$, respectively. The study pointed out that the ingredients of formulation failed in protect the bacteria during the hardening period at $-25 \mathrm{C}^{\circ}$, while the whey played a positive role to survive this bacterial during the seam period, especially when it was replaced with $60 \%$ of water. The results appeared significant lowering $(\mathrm{p}<0.05)$ the number of living bacteria after harding at $-25^{\circ} \mathrm{C}$ to $5 \times 103 \mathrm{c}$.f.u./g in the normal product, while the number of bacteria decreased to $9 \times 104,25 \times 105,12 \times 107$ c.f.u./g in the product which were the whey was replaced instead of water by $20 \%, 40 \%$ and $60 \%$. The study showed increased consumer acceptance of the products when supplemented by vanilla and blackberries flavor compared to the product without flavors.
\end{abstract}

Key words: Lactobacillus reuterl, sweet whey, ice cream

\section{INTRODUCTION}

Lactobacillus reuteri was considered as probiotic bacteria with good therapeutic properties. Several studies reported about the ability of this bacteria to improve the performance the host's digestive system and treatment of acute diarrhea in children [18]. Many researches noted that this bacterium effective as a therapeutic agent in frequent seizures and colic in both children and adults [2], in addition to its therapeutic role against many of the yeasts associated with digestive disorders [12]. Studies confirmed the role of this bacteria in lowering the level of cholesterol [11,17] and blood sugar [16] and treatment of heart disease patients and arteriosclerosis, Researches also indicated the role of this bacteria in helping infants to face their failure to tolerate lactose, especially in the first year after birth [16]. The researches has also discovered other advantages of these bacteria for immunodeficiency patients [19]. Because this bacteria play many beneficial roles for the host, it is important to deliver it to the consumer with a sense of vitality and activity that qualifies it to play the required role through many desired foods that serve as vehicle of these bacteria [13]. Ice cream is one of the most widely distributed food products in the world, thousands of tons of this product are consumed annually and in different forms. Since these products are favored by a broad spectrum of society, they have been used as vehicle of introducing therapeutic bacteria into the host's body [6]. Since most of the process of manufacturing this product is carried out in a refrigerated condition and through conditions that are almost sterile, these products were considered safe and suitable for the transfer of bacteria to the consumer. Lactobactllus reuterl was chosen as a locally isolation [3] and was used in the production of an ice-cream formulation after fortified with sweet- cheese whey to support it and increase the nutritional value of the final product and to rid the environment of one of the products of dairy factories that may cause environmental pollution due to poor dealing with it.

\section{MATERIALS AND METHODS}

1 - Locally isolation of Lactobacıllus reuterl it was received from the laboratories of the College of Agriculture / University of Baghdad, which isolated from the stool of exclusively breastfeeding infants who did not exceed 6 months. The bacteria were activated by passing it two times in the MRS broth with the addition of L- cystien and was incubated at $37 \mathrm{C}^{\circ} / 24 \mathrm{~h}$. Harrigan \& Mc-Cance, [8], AL-Dosaree, [3] and then it was activated once again in the sterile skim milk at $121 \mathrm{C}^{\circ}$ for 10 minutes and was incubated at $37 \mathrm{C}^{\circ} / 24 \mathrm{~h}[8]$.

2. The bacteria was added to the normal formulation of ice cream contain $10 \%$ fat, $11 \% \mathrm{SNF}, 10 \%$ sugar , $0.5 \%$ stabilizer and $68.5 \%$ water, and to another modified formulations contain the same compounds with $20 \%, 40 \%$ and $60 \%$ sweet whey instead of total water. All formulations were incubated at $37 \mathrm{C} / 24 \mathrm{~h}$. and then were used to manufacture ice cream formulation, was aging at $5 \mathrm{C}^{\circ} / 4$ hours.

3 - The proportion of fat in the whey was estimated according to the method described by Ling, [14]

4. The protein content in the whey was estimated according to the method described by A.O.A.C, [1]

5. The percentage of ash, moisture and total acidity in the whey was estimated according to the method was described by Marth, [15]

6. Vanilla and blackberries flavor was added to improve sensory evaluation and increase the consumer acceptance of the final product

7 - All formulations have been frozen at $-7 \mathrm{C}^{\circ}$ and have been harden at $-25 \mathrm{C}^{\circ} / 21$ Day.

8- The number of Lactobacillus reuterl was numeration after aging, freezing and hardening according Stander Plate Count by using MRS-Agar [8] and incubating at $37 \mathrm{C}^{\circ} / 24 \mathrm{~h}$. 
Citation: Ali Ameen Yaseen, 2018. Effect the addition of sweet whey on the survival of Lactobactllus reutert in the therapeutic ice cream. Advances in Environmental Biology., 12(6): 1-3.

\section{RESULTS AND DISCUSSION}

Table (1) shows the chemical composition of the sweet whey that used in this study, which was obtained by adding the microbial rennet to the pasteurized milk at $63 \mathrm{C} \% 30$ mint. The table shows that fat was $0.5 \%$, protein $0.9 \%$, lactose $4.0 \%$ and ash $0.4 \%$. While the acidity was 0.30 as a lactic acid, and pH 6 .

Table 1: The chemical composition of sweet whey.

\begin{tabular}{|c|c|c|c|c|c|c|c|c|}
\hline Compound & Fat $\%$ & Peotien $\%$ & Lactose $\%$ & Ash $\%$ & Dry matter\% & water $\%$ & Acidity & $\mathrm{pH}$ \\
\hline Sweet whey & 0.5 & 0.9 & 4.0 & 0.4 & 5.8 & 94.2 & 0.30 & 6 \\
\hline
\end{tabular}

The results in chart (1) show the why played a positive role in supporting and increasing the number of living Lactobacillus reuterl in the ice cream formulations in the end of aging period which followed the incubation period at $37 \mathrm{C}^{\circ} / 24 \mathrm{~h}$. The number of bacteria increased from $40 \times 10^{6} \mathrm{c}$. f.u $/ \mathrm{g}$. to $23 \times 10^{8} \mathrm{c}$. f.u./g in the normal formulation, while the number increased to become $13 \times 10^{9}, 80 \times 10^{9}$ and $19 \times 10^{12}$ c.f.u./g in the formulation which replaced the whey instead of water by $20 \%, 40 \%, 60 \%$ to respectively.

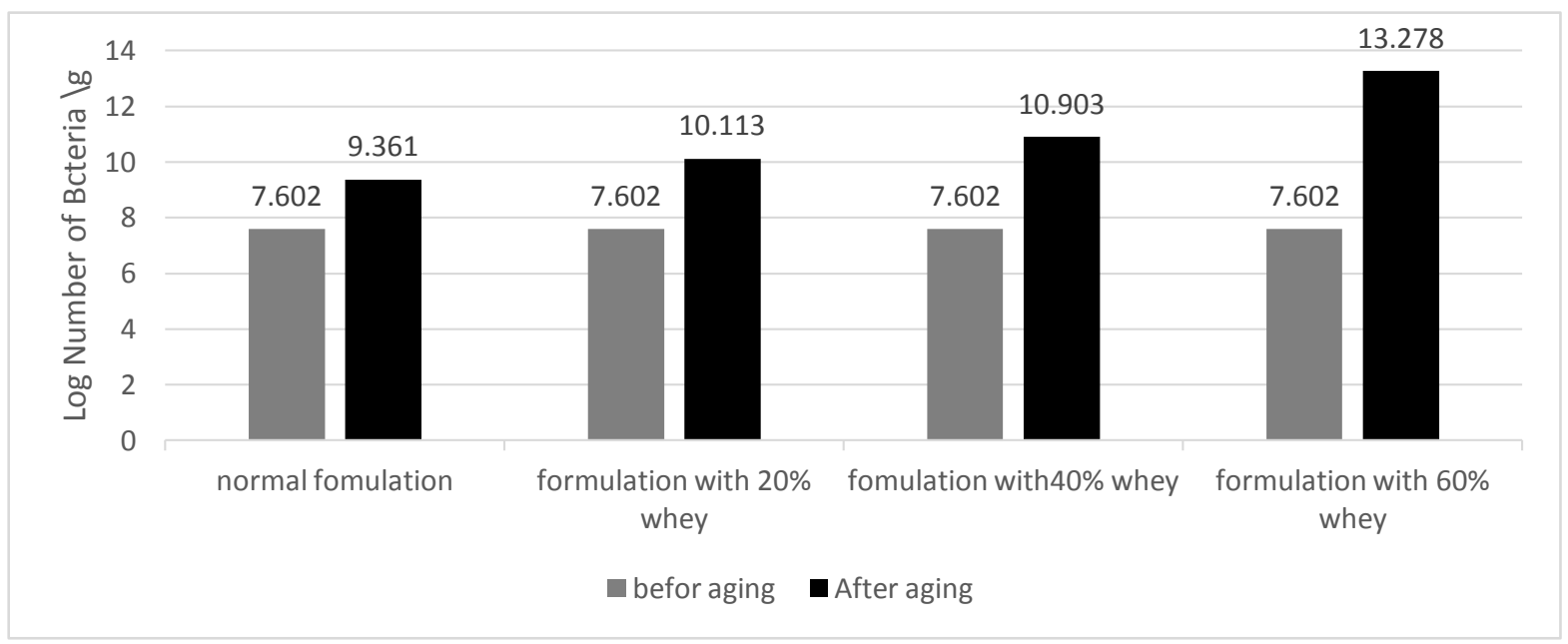

Chart 1: The role of the whey in increasing the number of bacteriareacti after the aging.

The results indicate that the increase number of bacteria was depending on the increase of whey's percentage in the formulation. This is due to the rich role of the whey for the environmental of bacteria, because the whey was considered as a rich source of lactose, peptides, free amino acids, minerals which support the microorganisms [5]. The results also point to a positive role of freezing process at $-7 \mathrm{C}^{\circ}$ on the numbers of bacteria. Chart (2) indicates that the living Lactobacillus reuterl increase in all the products after leaving the machine to reach $14 \times 10^{9}$ c.f.u. $/ \mathrm{g}$ in normal products while it became $25 \times 10^{9}, 24 \times 10^{11}$ and $30 \times 10^{12} \mathrm{c} . f . u . / \mathrm{g}$ In the products from formulation that have been replaced the water with $20 \%, 40 \%$ and $60 \%$ whey respectively. This increase may be due to the mechanical act of beating and stirring in the cooling cylinder of machine which fragmentation of colonies and bacterial cells that grew closely during the aging period. The process of scrambling accompanying with freezing and the presence of the stabilizer in the ice cream lead to formation of small ice crystals which can't play a negative role towards the bacteria in the product, as will as the high proportion of total solids in the ice cream formulation give a kind of protection for bacteria during the freezing stages [7].

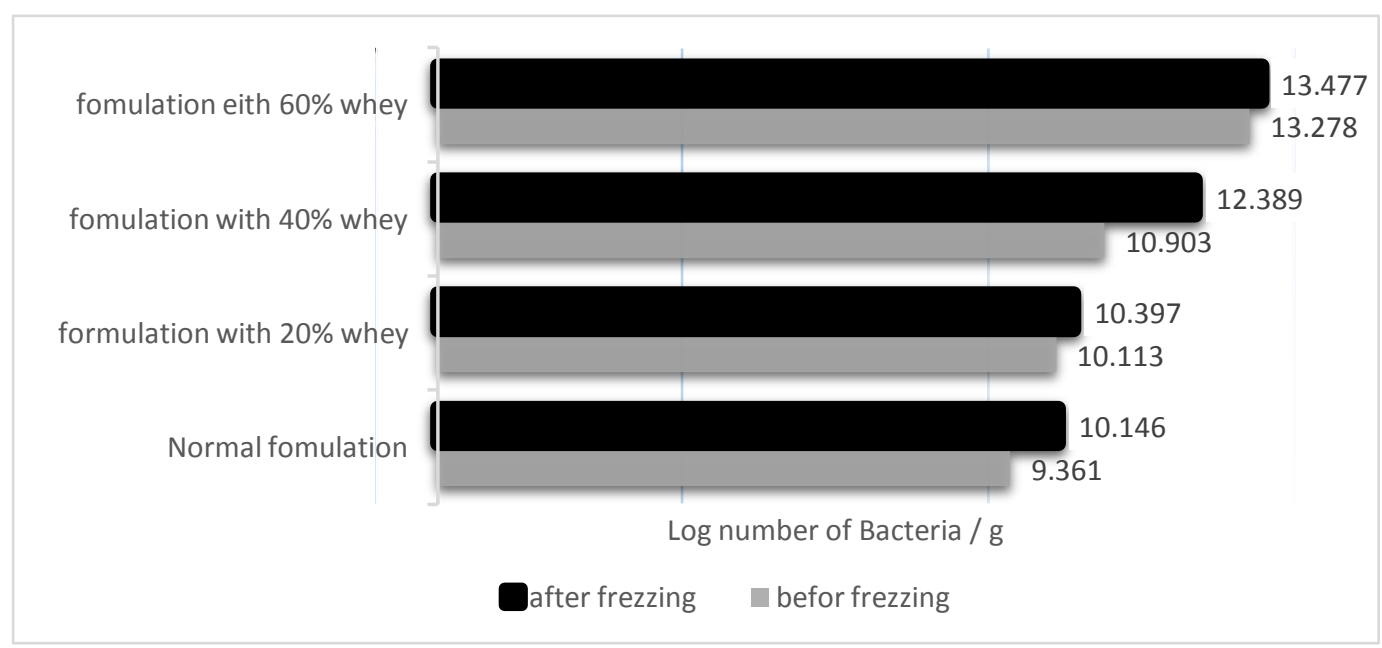

Chart 2: Effect of frozen storage periods on Lactobacillus reutert.

The results in chart (3) also show that the hardening period at $-25 \mathrm{C}^{\circ}$ played a negative role towards the Lactobacıllus reuterl and the components of the formulation did not provide protection for the bacteria during this period. The number of living cells decreased to $5 \times 10^{3} \mathrm{c} . \mathrm{f} . \mathrm{u}$. $/ \mathrm{g}$ after the third week in the nonmodified product. While the decrease of living cells were lower in products where the water was replaced by whey $20 \%, 40 \%, 60 \%$ to reach to $9 \times 10^{4}, 25 \times 10^{5}$ and $12 \times 10^{7}$ c.f.u/g respectively after the third week of storage. This decrease may be due to the mechanical act of large crystals of ice which formed during this period and the damage to the cell due freezing of free water inside cells. We can conclude that the increase of living bacteria in modify products especially the one 
contain $60 \%$ whey is due to the increase of the initial number of living cells before harding period, and this due to the supporting which provided from the whey during fermentation period before aging. As will as the protection role of total solids in the whey which save the bacteria during harding period.

The Adding vanilla or cranberry flavor to the final product has improved acceptance compared with the flavorless product. This is due to the unpleasant flavor caused by Lactobacillus reuteri during the period of growth in milk, especially since these bacteria was considered as hetero fermentation bacteria and therefore produce quantities of acetic acid and carbon dioxide and ethanol as well as their production of lactic acid [9].

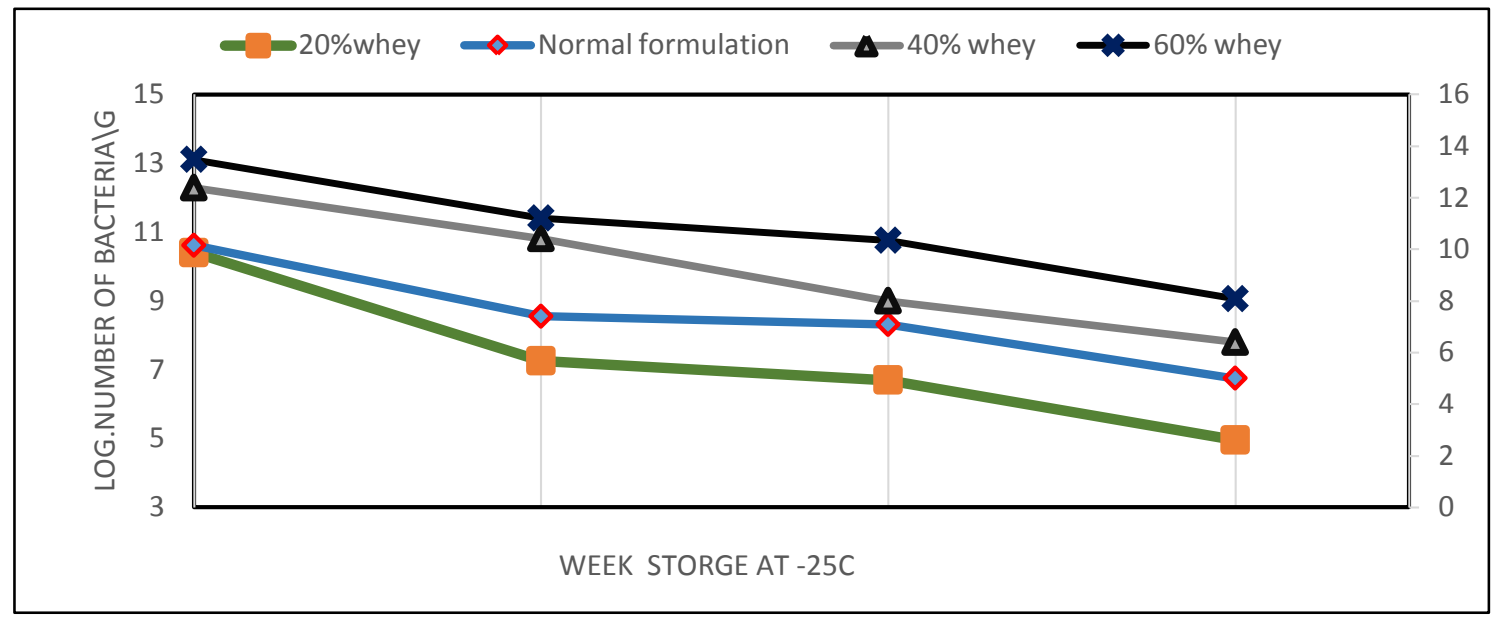

Chart 3: Effect of frozen storage periods on Lactobacillus reutert.

The results showed the volumetric standard of the antibody directed against Newcastle virus increased of the standard when ginger powder is used in bird feed, at $0.05 \%$ and $0.1 \%$ conc. Which amounted to 1024 comparison with sixth for control treatment, while the standard was 64 then using turmeric, then increased after 8 weeks, the treatment A3 was first lead, at age 5 and 8 weeks (Table 2).

\section{REFERENCES}

[1] A.O.A.C., 1970. Association of Official Chemists, $11^{\text {th }}$ ed, Washigton D.C. USA.

[2] Abrahamsson, T.R., G. Sinkiewicz, T. Jakobsson, M. Fredrikson, B. Bjorksten, 2009. Probiotic lactobacilli in breast milk and infant stool in relation to oral intake during the first year of life. J Pediatr Gastroenterol Nutr., 49: 349-354.

[3] AL-dosaree, A.A., 2002. Study of some Physiologycal characteristics of Loca isolation of Lactobaciluus reuteri and use it to prodused theraputic Dairy products, Ph.D. thesses, golleg of Agriculture, Baghdad University.

[4] Fatheree, N.Y., Y. Liu, C.M. Taylor, T.K. Hoang, C. Cai, M.H. Rahbar, M. Hessabi, M. Ferris, V. McMurtry, C. Wong, T. Vu, T. Dancsak, T. Wang, W. Gleason, V. Bandla, F. Navarro, D.Q. Tran, J.M. Rhoads, 2017. Lactobacillus reuteri for Infants with Colic: A Double-Blind, Placebo-Controlled, Randomized Clinical Trial. J. Pediatr., 191: 170-178.

[5] Ha, E., M.B. Zemel, 2003. Functional properties of whey, whey componets and essential ameenoacids: Mechanism under lying health benefits for activite people, J. Nutr. Biochem., 14: 251-258.

[6] Hagen, M. and A. Judith, 1999. Production of ice cream containing probiotic bacteria, Milchwissenshaft, 54(5): 265-268.

[7] Hamayouni, A., M.R. Ehsani, A. Azizi, S.H. Razavi and M.S. Yarmand, 2008. Growth and survival of some strains in simulated ice cream conditions, Journal of Applied Sciences, 8(2): 379-283.

[8] Harrigan, W.F. and M.E. Mc-Cans, 1976. Labrotary methods in Microbiology, Academic Press. London, U.K.

[9] Hidetoshi, M., Toh, T. Hidehiro, F. Shinji, 2008. "Comparative Genome Analysis of Lactobacillus reuteri and Lactobacillus fermentum Reveal a Genomic Island for Reuterin and Cobalamin Producion. J. DNA Research, 15: 151-161.

[10] Ianniello, R.G., J. Zheng, T. Zotta, A. Ricciardi, M.G. Ganzle, 2015. Biochemical analysis of respiratory metabolism in the heterofermentative Lactobacillus spicheri and Lactobacillus reuteri. J. Appl. Microbiol., 119(3): 763.

[11] Jones, M.L., C.J. Martoni, M. Parent, S. Prakash, 2012. Cholesterol-lowering efficacy of a microencapsulated bile salt hydrolase-active Lactobacillus reuteri NCIMB 30242 yoghurt formulation in hypercholesterolaemic adults. Br. J. Nutr., 107(10): 1505-1518.

[12] Jorgensenö Mr., C. Kragelund, Jensen, Po., Keller, Mk., S. Twetman, 2017. Probiotic Lactobacillus reuteri has antifungal on oral Candida species in vitro, J. Oral Microbial, 18: 9-10.

[13] Kailasapathy, K., S. Rybka, 1997. Lactobacillus acidophilus and Bifidobacterium spp. their therapeutic potential and survival in yogurt, Australian Journal of Dairy Technology; Melbourne, 52(1): 28-35.

[14] Ling, E.R., 1963. A test Book Dairy Chemistry II, Chapman and Hall Ltd. London, UK.

[15] Marth, E.H., 1978. Standert Methods for the Examination of Dairy Products14th ed. Interdisciplinary Books and Periodicals for the professinal and Layman.

[16] Speeke, M.L., W.J. Dobrogosz, I. Casas, 1993. Lactobacillus reuteri in food supplementation, J. food Technol, Anon, 90-94.

[17] Taranto, M.P., F. Sesma, Pesce de Ruiz, G.F. Valdez, 1997. Bile salt hydrolase plays a key role on cholesterol removal by Lactobacillus reuteri, J. Biotechnology Letters, 19(9):845.

[18] Urbanska, M1, D. Gieruszczak-Białek, H. Szymanski, H. Szajewska, 2016, Effectiveness of Lactobacillus reuteri DSM 17938 for the Prevention of Nosocomial Diarrhea in Children: A Randomized, Double-blind, Placebo-controlled Trial. Pediatr Infect Dis. J., 35(2): 142-147.

[19] Wolfz, B.W., K.B. Wheelerz, D.G. Atayaz, K.A. Garlebz, 1998. Safety and tolerance of Lactobacillus reuteri supplementation to a population infected with the human immunodeficiency virus ,jurnal Food and Chemical Toxicolog, 36(12): 1085-1094. 